\title{
Fuel Fabrication Development for the Surrogate Sphere-Pac Rodlet
}

\author{
July 2005
}

Prepared by
G. D. Del Cul
C. H. Mattus
A. S. Icenhour
L. K. Felker
D. F. Williams 


\section{DOCUMENT AVAILABILITY}

Reports produced after January 1, 1996, are generally available free via the U.S. Department of Energy (DOE) Information Bridge:

Web site: http://www.osti.gov/bridge

Reports produced before January 1, 1996, may be purchased by members of the public from the following source:

National Technical Information Service

5285 Port Royal Road

Springfield, VA 22161

Telephone: 703-605-6000 (1-800-553-6847)

TDD: 703-487-4639

Fax: 703-605-6900

E-mail: info@ntis.fedworld.gov

Web site: http://www.ntis.gov/support/ordernowabout.htm

Reports are available to DOE employees, DOE contractors, Energy Technology Data Exchange (ETDE) representatives, and International Nuclear Information System (INIS) representatives from the following source:

Office of Scientific and Technical Information

P.O. Box 62

Oak Ridge, TN 37831

Telephone: $865-576-8401$

Fax: $865-576-5728$

E-mail: reports@adonis.osti.gov

Web site: http://www.osti.gov/contact.html

This report was prepared as an account of work sponsored by an agency of the United States Government. Neither the United States government nor any agency thereof, nor any of their employees, makes any warranty, express or implied, or assumes any legal liability or responsibility for the accuracy, completeness, or usefulness of any information, apparatus, product, or process disclosed, or represents that its use would not infringe privately owned rights. Reference herein to any specific commercial product, process, or service by trade name, trademark, manufacturer, or otherwise, does not necessarily constitute or imply its endorsement, recommendation, or favoring by the United States Government or any agency thereof. The views and opinions of authors expressed herein do not necessarily state or reflect those of the United States Government or any agency thereof. 
ORNL/TM-2005/108

Nuclear Science and Technology Division

FUEL FABRICATION DEVELOPMENT FOR THE SURROGATE SPHERE-PAC RODLET
G. D. Del Cul
C. H. Mattus
A. S. Icenhour
L. K. Felker
D. F. Williams

Date Published: July 2005

Prepared by

OAK RIDGE NATIONAL LABORATORY

P.O. Box 2008

Oak Ridge, Tennessee 37831-6283

managed by

UT-BATTELLE, LLC

for the

U.S. DEPARTMENT OF ENERGY

under contract DE-AC05-00OR22725 



\section{CONTENTS}

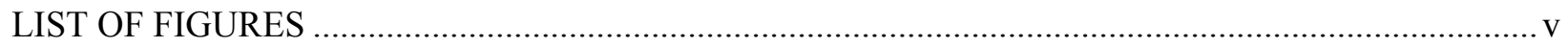

ACRONYMS AND ABBREVIATED FORMS .............................................................................. vii

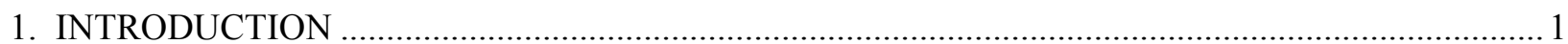

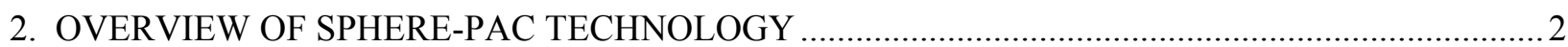

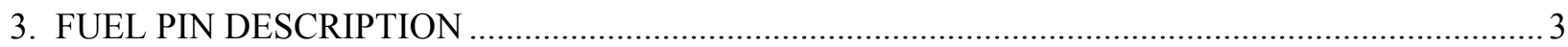

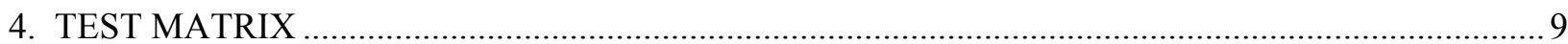

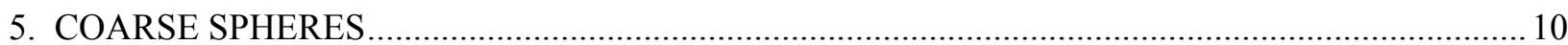

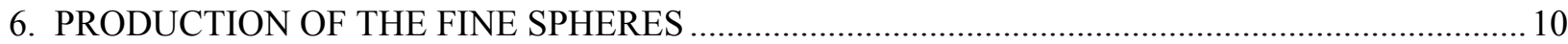

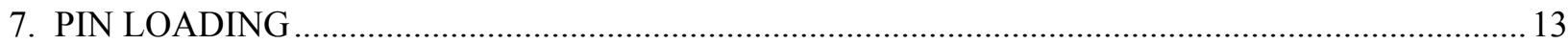

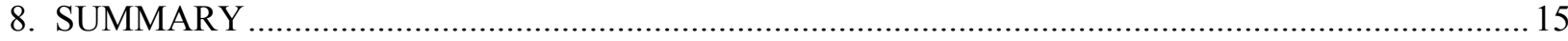

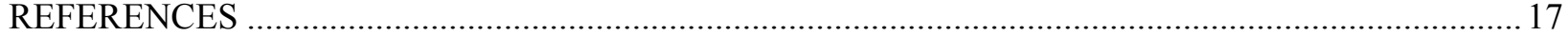





\section{LIST OF FIGURES}

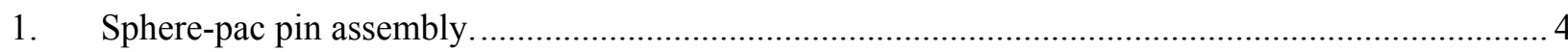

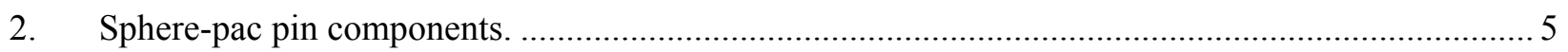

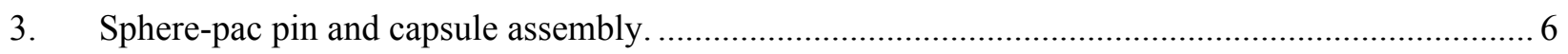

4. X-ray imaging system for density profiling in the sphere-pac fuel column.................................. 8

5. Sample X-ray image of LWR rod containing hafnia microspheres. ............................................ 9

6. Particle size distribution of the $\mathrm{Yb}_{2} \mathrm{O}_{3}$ produced by ion-exchange loading on Bio-Rex 70 resin and subsequent calcination. ....................................................................... 12

7. Quartz "fuel rod" and glass beads used to test and optimize loading conditions........................... 14

8. Accelerometer used to impart a reproducible vibration motion to load the pin............................. 14

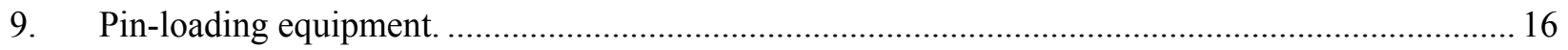

10. Follower rod (lower left) along with fuel pin and screw feeder................................................... 16 



\section{ACRONYMS AND ABBEVIATED FORMS}

$\begin{array}{ll}\text { AFCI } & \text { Advanced Fuel Cycle Initiative } \\ \text { AGR } & \text { Advanced Gas Reactor } \\ \text { ATR } & \text { Advanced Test Reactor } \\ \text { FCCI } & \text { fuel-clad chemical interaction } \\ \text { FCMI } & \text { fuel-clad mechanical interaction } \\ \text { INL } & \text { Idaho National Laboratory } \\ \text { LWR } & \text { light-water reactor } \\ \text { ORNL } & \text { Oak Ridge National Laboratory }\end{array}$





\section{INTRODUCTION}

Sphere-pac fuel consists of a blend of spheres of two or three different size fractions contained in a fuel rod. ${ }^{1-5}$ The smear density of the sphere-pac fuel column can be adjusted to the values obtained for light-water reactor (LWR) pellets (91-95\%) by using three size fractions, and to values typical of the fastreactor oxide fuel column ( $85 \%)$ by using two size fractions. For optimum binary packing, the diameters of the two sphere fractions must differ by at least a factor of 7 (ref. 3). Blending of spheres with smaller-diameter ratios results in difficult blending, nonuniform loading, and lower packing fractions. ${ }^{5}$ A mixture of about 70 vol \% coarse spheres and 30 vol \% fine spheres is needed to obtain high packing fractions. ${ }^{2,6,7}$ The limiting smear density for binary packing is $86 \%$, with about $82 \%$ achieved in practice. Ternary packing provides greater smear densities, with theoretical values ranging from 93 to $95 \%$.

Sphere-pac technology was developed in the 1960-1990 period for thermal and fast spectrum reactors of nearly all types (U-Th and U-Pu fuel cycles, oxide and carbide fuels), but development of this technology was most strongly motivated by the need for remote fabrication in the thorium fuel cycle. The application to LWR fuels as part of the DOE Fuel Performance Improvement Program did not result in commercial deployment for a number of reasons, but the relatively low production cost of existing $\mathrm{UO}_{2}$ pellet fuel is probably the most important factor. In the case of transmutation fuels, however, sphere-pac technology has the potential to be a lower-cost alternative while also offering great flexibility in tailoring the fuel elements to match the exact requirements of any particular reactor core at any given time in the cycle. In fact, the blend of spheres can be adjusted to offer a different composition for each fuel pin or group of pins in a given fuel element. Moreover, it can even provide a vertical gradient of composition in a single fuel pin. For minor-actinide-bearing fuels, the sphere-pac form is likely to accept the large helium release from ${ }^{241} \mathrm{Am}$ transmutation with less difficulty than pellet forms and is especially well suited to remote fabrication as a dustless fuel form that requires a minimum number of mechanical operations. The sphere-pac (and vi-pac) fuel forms are being explored for use as a plutonium-burning fuel by the

European Community, the Russian Federation, and Japan. ${ }^{8-12}$

Sphere-pac technology supports flexibility in the design and fabrication of fuels. For example, the blend composition can be any combination of fissile, fertile, transmutation, and inert components. Since the blend of spheres can be used to fill any geometric form, nonconventional fuel geometries (e.g., annular fuels rods, or annular pellets with the central region filled with spheres) ${ }^{13,14}$ are readily fabricated using sphere-pac loading methods. 
A project, sponsored by the U.S. Department of Energy Advanced Fuel Cycle Initiative (AFCI), has been initiated at Oak Ridge National Laboratory (ORNL) with the objective of conducting the research and development necessary to evaluate sphere-pac fuel for transmutation in thermal and fast-spectrum reactors. This AFCI work is unique in that it targets minor actinide transmutation and explores the use of a resin-loading technology for the fabrication of the remote-handled minor actinide fraction.

While there are extensive data on sphere-pac fuel performance for both thermal-spectrum and fastspectrum reactors, there are few data with respect to their use as a transmutation fuel. The sphere-pac fuels developed will be tested as part of the AFCI LWR-2 irradiations.

This report provides a review of development efforts related to the fabrication of a sphere-pac rodlet containing surrogate fuel materials. The eventual goal of this activity is to develop a robust process that can be used to fabricate fuels or targets containing americium. The report also provides a review of the materials, methods, and techniques to be used in the fabrication of the surrogate fuel rodlet that will also be used in the actual LWR-2 irradiation specimen.

\section{OVERVIEW OF SPHERE-PAC TECHNOLOGY}

Vibratory consolidation of spherical granules (sphere-pac) or irregular granules (vi-pac) is the primary method for loading fuel pins with particle-bed fuels. Sphere-pac particles are produced by carefully regulated wet-chemical methods, whereas vi-pac particles are produced by crushing or milling. Both techniques use vibration to increase the density of the fuel during loading and multiple sizes to achieve a high packing fraction.

Peddicord et al. provide a review of the development of sphere-pac fuels up to $1986 .^{2}$ Other sources provide a more comprehensive summary of the methods used to produce spherical fuel particles, rod-

loading techniques, quality assurance methods, and irradiation experience. ${ }^{3-5}$ All of these authors indicate that the use of sphere-pac fuels offers several advantages. The wet-chemical production methods for spheres require fewer mechanical steps than does pellet production, ${ }^{15}$ and no dust is produced. In addition, the fuel production and fabrication methods can be adapted to remote operations - an important consideration for use with minor actinide transmutation fuels. Irradiation test data show less fuel-clad mechanical interaction (FCMI) as compared with pellet fuel, which results in reduced strain and probability of pin failure by stress corrosion cracking. There is also evidence of reduced fuel-clad chemical interaction (FCCI). However, Peddicord et al. indicate that there is still an open question as to whether this advantage is maintained during rapid power transients at the beginning of fuel irradiation. ${ }^{2}$

Methods that have been used to produce all types and sizes of spheres include water extraction gelation, external chemical gelation, and internal chemical gelation. ${ }^{2}$ A recent ORNL report ${ }^{15}$ describes 
the internal gelation method in detail. To make the smaller-size particles, resin-loading methods have been used at ORNL for the production of ${ }^{244} \mathrm{Cm}$ targets ${ }^{16}$ and ${ }^{233} \mathrm{U}$ fuels. ${ }^{17-18}$ Resin-loading methods are proposed for production of the minor actinide spheres because of the simplicity of the process for remote operations and the very low level of waste generation.

Two techniques have been proven effective for loading particles in the fuel column: (a) infiltration of small spheres into a bed of large spheres with vibratory energy, and (b) simultaneous blending of the various particle size fractions during a single vibration-assisted loading operation. The blending option was developed in order to load long fuel pins in the fastest time for plant-scale applications. The infiltration method is commonly used in the laboratory and gives good results if certain guidelines are followed. For both types of fuel-pin loading, the inner diameter of the tube should be at least ten times the diameter of the largest particle diameter. In order to achieve good infiltration, the larger spheres must be held in place to prevent levitation of the bed by the smaller spheres. Multidirectional and variable frequency vibration is sometimes used to facilitate rod loading. ${ }^{2}$ After loading, pins are inspected by nondestructive techniques (i.e., X-ray and gamma densitometry, autoradiography) to verify the uniformity of the fuel column. ${ }^{19}$

\section{FUEL PIN DESCRIPTION}

The fuel pins to be tested are based on the design used for the Fissile Material Disposition Program mixed oxide (MOX) and AFCI LWR-1 irradiations. A typical pin assembly, pin components, and pin and capsule assembly are shown in Figs. 1-3, respectively. The fuel pins will be fabricated with Zircaloy-IV, but the surrogate fuel pins will be fabricated from stainless steel in an equivalent pin geometry. A standin fabrication package for the surrogate fuel rod will be used to document material certifications and inspections required for the eventual LWR-2 pins.

The LWR-series test-fuel pins are nominally 8.09 in. long and have an outside diameter of 0.3810 in. Typical parameters of the LWR-series pin are provided in Table 1, along with the particular parameters for the surrogate rodlet and the LWR-2 rodlet. The fuel column will consist of two size fractions of spheres and will be about 5 in. long. The coarse fraction will consist of 500- to $800-\mu \mathrm{m}$ spheres, while the fine fraction will consist of 50- to $80-\mu \mathrm{m}$ spheres. The composition of the microspheres is described in the next section. A hafnia insulating pellet (identical to that used in LWR-1) is used on each end of the fuel column to hold it in place. The top of the column is held down by a spring, which also provides for a plenum region above the column. 

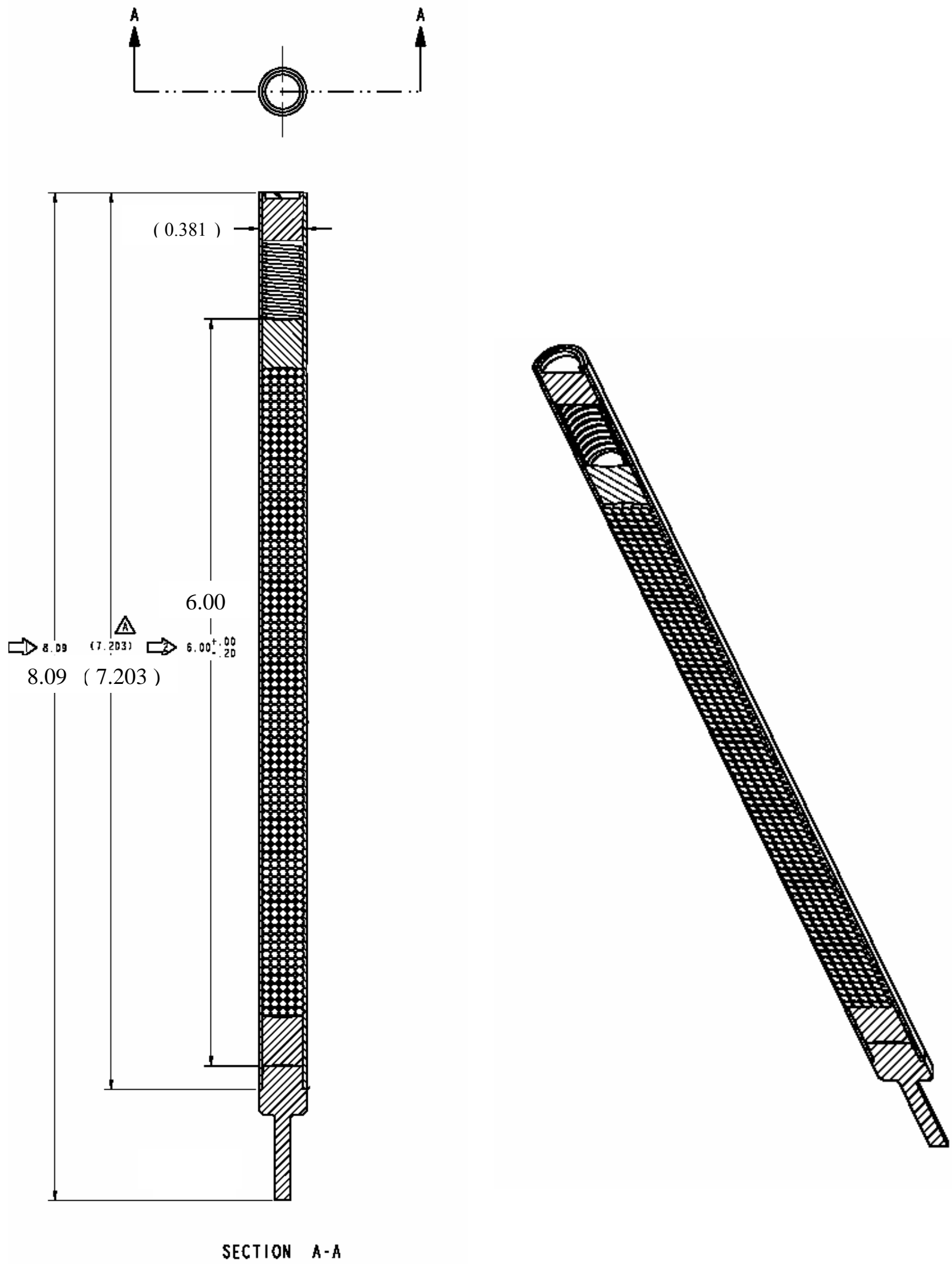

Fig. 1. Sphere-pac pin assembly. 

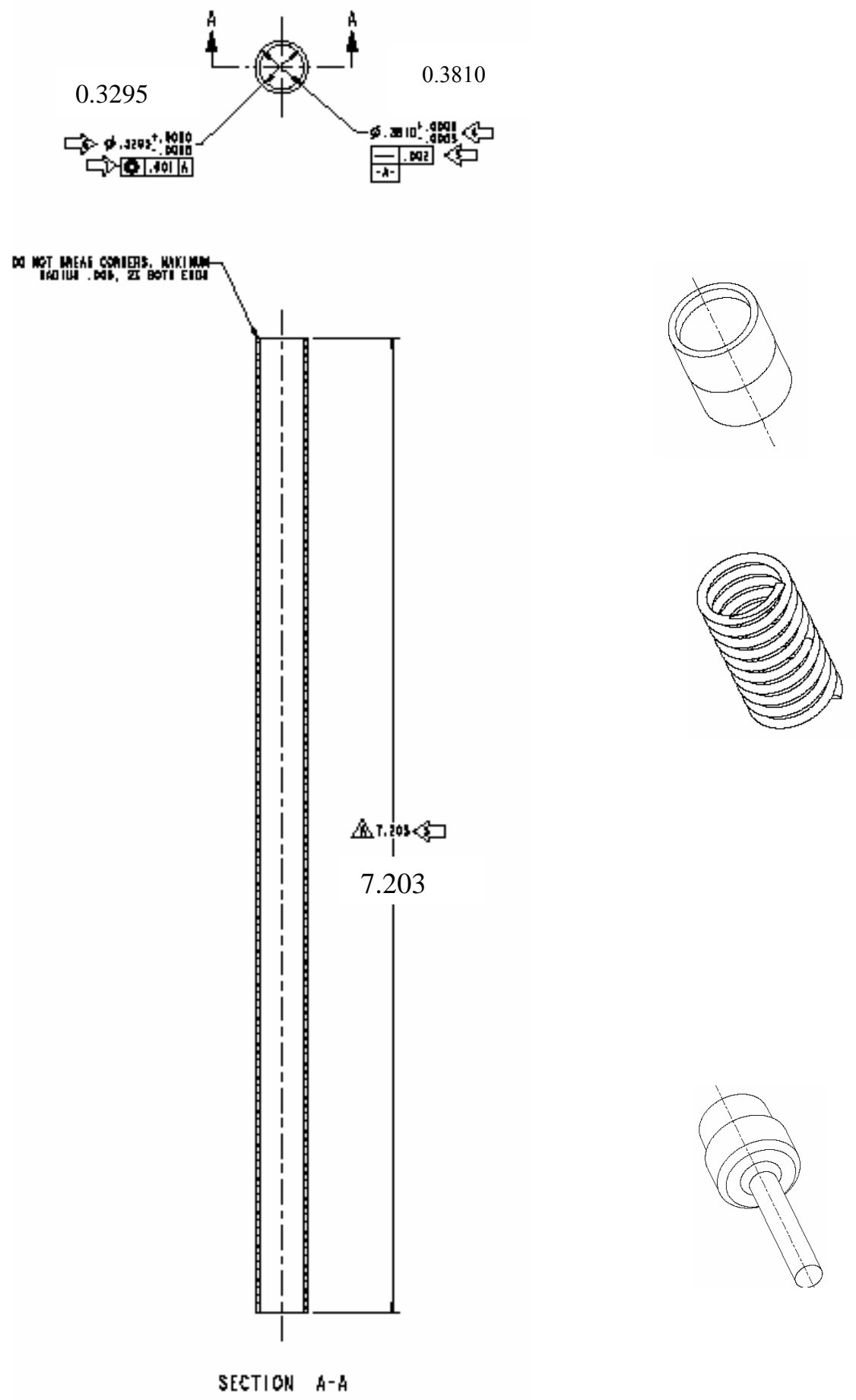

Fig. 2. Sphere-pac pin components. 


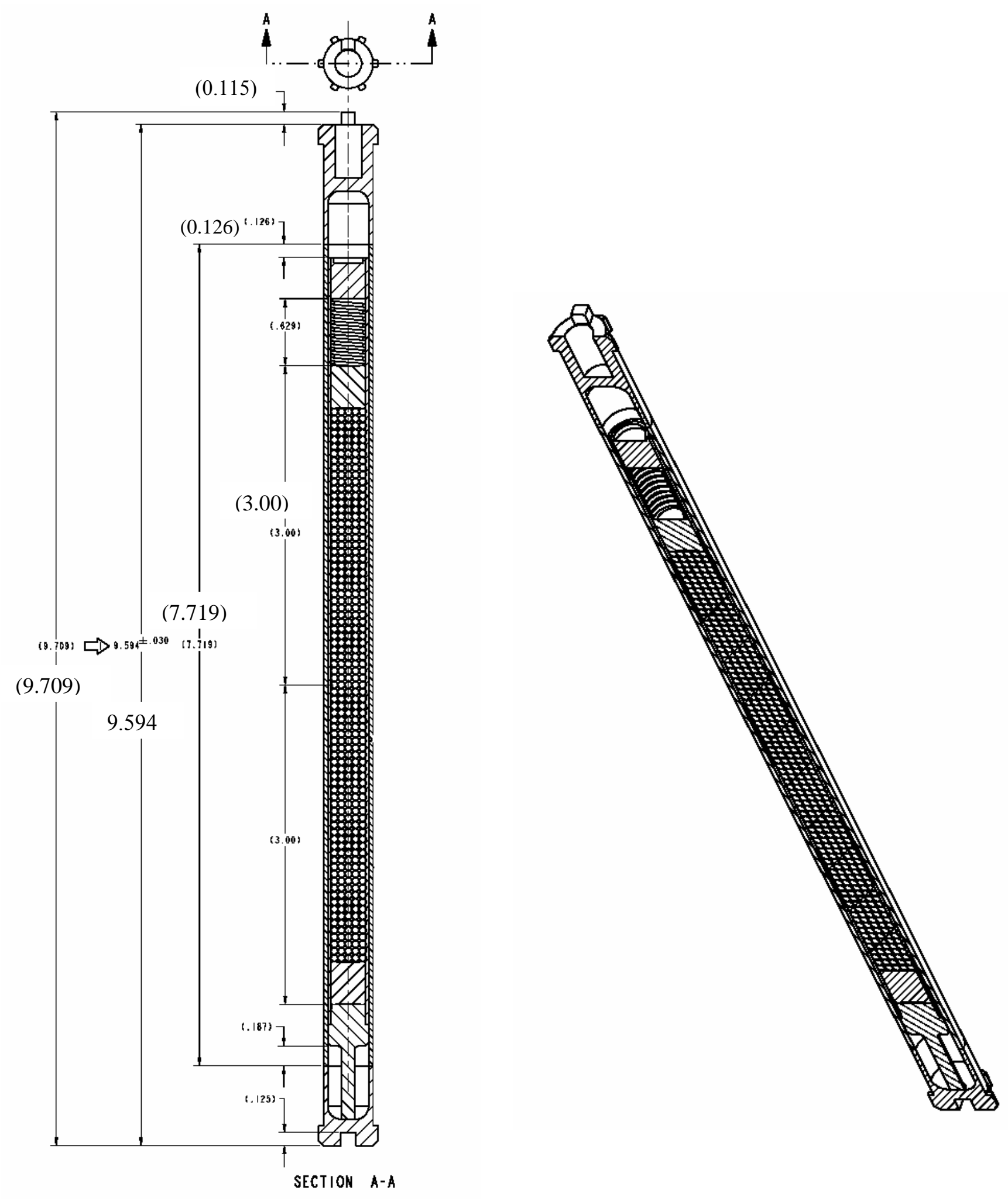

Fig. 3. Sphere-pac pin and capsule assembly. 
Table 1. Sphere-pac pin parameters ${ }^{a}$

\begin{tabular}{lcc}
\hline & \multicolumn{2}{c}{ Material Parameters } \\
\cline { 2 - 3 } Cladding & Surrogate rodlet & LWR-2 rodlet \\
\cline { 2 - 3 } Large spheres & 316 stainless steel & Zircaloy-IV \\
Small spheres & $\mathrm{HfO}_{2}$ & $\mathrm{ZrO}_{2}, \mathrm{UO}_{2}$ \\
& Rare-earth oxide $\left(\mathrm{Yb}_{2} \mathrm{O}_{3}\right)$ & $\mathrm{Am}$ oxide and filler \\
$(\mathrm{UO}$ & $\mathrm{Zr})$
\end{tabular}

${ }^{a}$ Common pin parameters: cladding O.D., 0.3810 in.; cladding I.D., 0.3295 in.; bond material, helium; fuel type, oxide; fuel smear density, $82 \%$; fuel height, 5 in.

The fuel pin will be loaded with microspheres using specially designed equipment and procedures to control the loading. Documentation of the microsphere properties (size, density, composition, impurities), fuel column properties (smear density/uniformity), and pin-loading operations will be provided as part of the fabrication documents for both the surrogate rodlet and the LWR-2 rodlet. After loading, the cap will be welded into the pin, and the welded assembly will be helium leak checked. The pin will then be radiographed and inspected prior to shipment. The surrogate rodlet will be used to test interferences and troubleshoot other aspects of acceptance of the sphere-pac fuel form for irradiation in the Advanced Test Reactor (ATR). The actual LWR-2 rodlet will be received and inspected at Idaho National Laboratory (INL), and the pins will be enclosed in capsules provided by INL. The capsules are also based on the LWR-1 design. The capsule/pin assembly (Fig. 3) will then be loaded into a basket in preparation for insertion into the ATR. The basket will be fabricated by INL.

The nonfuel components of the LWR-2 rodlet are essentially identical to those used in the LWR-1 irradiation. Welding procedures for the LWR-1 rodlets were developed at Los Alamos National Laboratory in collaboration with ORNL experts. These same welding techniques will be deployed in existing facilities at ORNL designed for inert-atmosphere welding of transuranic (TRU)-containing packages for the actual TRU rodlets. Stainless steel welding procedures and capabilities to support the surrogate rod fabrication currently exist at ORNL.

The primary difference in this LWR-2 irradiation is the novel sphere-pac fuel form. Both the spheres and the fuel column will be characterized. The large spheres for the surrogate rodlet will be a commercial material $\left(\mathrm{HfO}_{2}\right)$. The impurities of this material will not be measured because they play no role in the function of this material as a surrogate. However, impurity information provided by the manufacturer will be used to evaluate the material's suitability for use in future irradiations. Because the purpose of surrogate rod fabrication is to prepare for fabrication of the actual fuel rodlet, the sphere characterization measurements listed in Table 2 will be performed for both the surrogate rodlet and the LWR-2 rodlet. 
Table 2. Sphere characterization measurements

\begin{tabular}{llll}
\hline Property & Method for surrogate & Method for LWR-2 & Status at ORNL \\
\hline Impurities & Not applicable & ICP-AES $^{a}$ & Existing \\
Phase Content & Not applicable & X-ray diffraction & Existing \\
Size & Precision screening & Precision screening & Existing \\
Density, bulk & Tap density & Tap density & Existing \\
Density, skeletal & Helium pycnometry & Helium pycnometry & Existing
\end{tabular}

${ }^{a}$ ICP-AES - Inductively Coupled Plasma Atomic Emission Spectrometer.

${ }^{b}$ Apparatus to be deployed in a glove box for the americium-containing material.

For those properties we do not propose to measure, the surrogate rod will serve as an exemplar for the actual LWR-2 measurement. Much of the sphere-characterization procedures have been developed in conjunction with the ongoing Advanced Gas Reactor (AGR) Program for analysis of the kernels in coated- particle fuel.

Testing for uniformity of material loaded into the fuel column will also be necessary. In the past this measure of uniformity was determined by gamma densitometry. ${ }^{19}$ We will use a more modern X-ray system that currently exists at ORNL to perform this type of density profiling. The ORNL X-ray system is shown in Fig. 4, and a sample X-ray image of an LWR rod obtained during preliminary testing is shown in Fig. 5. The surrogate rodlet will be used to begin the optimization of this equipment for density profiling of the fuel column.
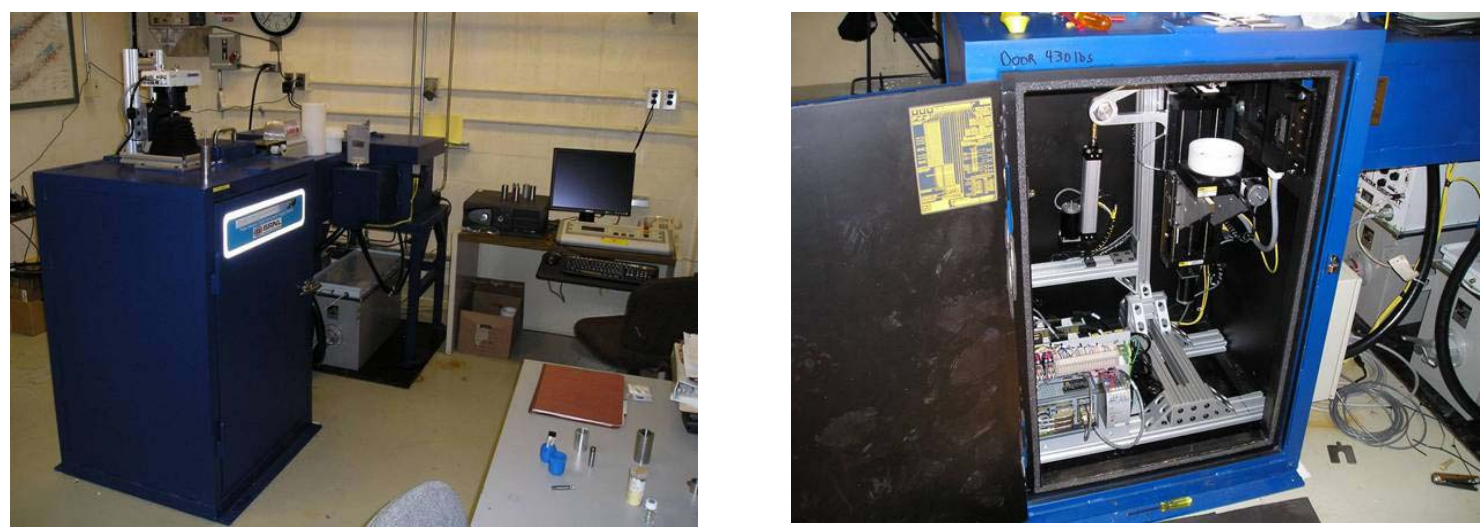

Fig. 4. X-ray imaging system for density profiling in the sphere-pac fuel column. 


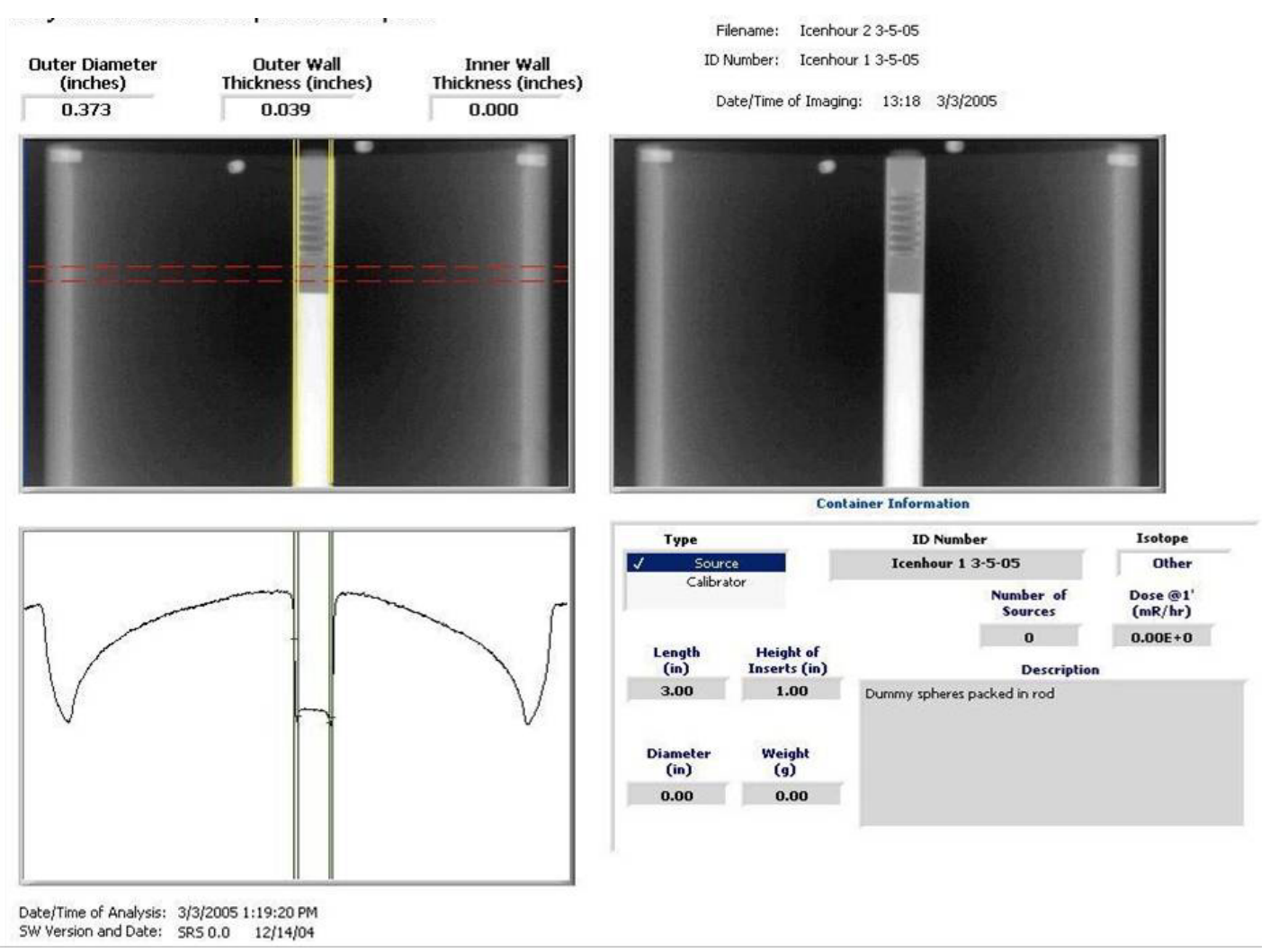

Fig. 5. Sample X-ray image of LWR rod containing hafnia microspheres.

\section{TEST MATRIX}

The surrogate rodlet is intended to serve as a stand-in for all three types of sphere-pac pins proposed for irradiation: (1) an americium target, which consists of $\mathrm{ZrO}_{2}$ and $\mathrm{AmO}_{2}$ spheres; (2) a $\mathrm{UO}_{2} / \mathrm{AmO}_{2}$ fuel pin; and (3) a $\mathrm{UO}_{2} / \mathrm{AmO}_{2} / \mathrm{Zr}$ fuel pin. The last option includes an addition of small metallic zirconium particles and is motivated by recent work at the Paul Scherrer Institute that indicates much better performance can be obtained with this "cermet" variant. ${ }^{20}$

The compositions proposed for LWR-2 irradiation tests are shown in Table 3. All sphere-pac compositions are estimated based on the following assumptions: smear density, $82 \%$; coarse fraction, $70 \mathrm{vol} \%$; fine fraction, $30 \mathrm{vol} \%$; coarse spheres, $95 \%$ theoretical density; and fine spheres, $60 \%$ theoretical density. The final LWR-2 compositions may need to be changed based on the analysis of their expected performance in the ATR. However, it is expected that the values given in Table 3 are reasonable estimates. 
Table 3. Estimated compositions of sphere-pac pins

\begin{tabular}{|c|c|c|c|c|c|c|c|c|}
\hline \multicolumn{2}{|c|}{ Sphere composition } & \multirow{2}{*}{$\begin{array}{l}\text { Uranium } \\
\text { enrichment } \\
\text { (wt \%) }\end{array}$} & \multirow[t]{2}{*}{$\begin{array}{l}\text { Americium } \\
(\mathrm{wt} \%)\end{array}$} & \multicolumn{4}{|c|}{$\begin{array}{l}\text { Mass } \\
(\mathrm{g})\end{array}$} & \multirow{2}{*}{$\begin{array}{l}\text { Irradiation } \\
\text { time } \\
\text { (years) }\end{array}$} \\
\hline Coarse & Fine & & & $\mathrm{UO}_{2}$ & $\mathrm{AmO}_{2}$ & $\mathrm{ZrO}_{2}$ & $\mathrm{Zr}$ & \\
\hline $\mathrm{ZrO}_{2}$ & $\begin{array}{c}\mathrm{ZrO}_{2} \text { and } \\
\mathrm{AmO}_{2}\end{array}$ & -- & 10 & -- & 3.1 & 24.5 & -- & 2 \\
\hline $\mathrm{UO}_{2}$ & $\begin{array}{c}\mathrm{UO}_{2} \text { and } \\
\mathrm{AmO}_{2}\end{array}$ & 5 & 5 & 48.2 & 2.9 & -- & -- & 1 \\
\hline $\mathrm{UO}_{2}$ & $\begin{array}{c}\mathrm{UO}_{2} \text { and } \\
\mathrm{AmO}_{2}\end{array}$ & 5 & 10 & 45.4 & 5.8 & -- & -- & 1 \\
\hline $\mathrm{UO}_{2}$ & $\begin{array}{l}\mathrm{Zr} \text { and } \\
\mathrm{AmO}_{2}\end{array}$ & 5 & 10 & 39.6 & 5.5 & -- & 3.6 & 2 \\
\hline
\end{tabular}

\section{COARSE SPHERES}

The surrogate rodlet will contain commercially available $\mathrm{HfO}_{2}$ microspheres in the 500 - to $800-\mu \mathrm{m}$ size range (Brace $\mathrm{GmbH})$. The coarse fraction for LWR-2 will consist of 500- to 800- $\mu \mathrm{m}$ spheres of two different compositions: $\mathrm{UO}_{2}\left(\sim 5 \%{ }^{235} \mathrm{U}\right)$ and $\mathrm{ZrO}_{2}$. Fabrication of $\mathrm{UO}_{2}$ for the $\mathrm{LWR}-2$ irradiation specimen will be carried out by procedures previously developed by ORNL and used for making depleted uranium kernels for coating studies in the AGR Program. ${ }^{15}$

\section{PRODUCTION OF THE FINE SPHERES}

Dense packing of a binary mixture of spheres is obtained only if the diameters of the two sphere fractions differ by at least a factor of 7 (ref. 4). A diameter ratio of 10 was adopted in this study to ensure that good packing will be obtained. The coarse fraction will consist of 500 - to $800-\mu \mathrm{m}$ spheres produced by internal gelation, and the fine fraction will consist of $50-$ to $80-\mu \mathrm{m}$ spheres. For the smaller-sized spheres, a microsphere production method that offers advantages over the internal gelation process may prove beneficial. A resin-loading method has been successfully used for many years at ORNL for the preparation of actinide targets for heavy-element production. ${ }^{16}$ This method was chosen because of its simplicity and ability to produce the smaller-size fraction with almost no waste. The method consists of (a) ion-exchange sorption of the metal species (either americium or uranium) onto the resin, (b) heat treatment in oxygen (calcination) to produce a metal-oxide residue, and (d) densification of the metal oxide by sintering in a controlled atmosphere (usually $4 \% \mathrm{H}_{2}$ ). Because the initial resin particles are spherical, the residual particles after sintering are also spherical. The final density and size of the 
particles depend on the initial size of the resin, the amount of metal sorbed on the resin, and the calcining and sintering conditions. It is usually not possible to produce fully dense spheres by this method, but densities somewhat above $50 \%$ of the theoretical limit can be made.

For our present project, three resins have been evaluated. Two are strong-acid cation resins containing sulfonate groups-DOWEX 50W-X8 resin and the macroporous equivalent Bio-Rad AG-MP-50. The third is a weak-acid cation resin, BioRex 70, based on carboxylate groups. The three are being evaluated with respect to potential impurities as well as the characteristics (e.g., size, density, porosity, crush strength) of the product spheres.

The strong-acid cation resins are known to provide relatively high loadings from acidic solutions but require a three-step calcination, produce corrosive off-gas products, and may suffer from sulfur contamination of the final oxide product. In this document we report on the weak-acid anion resins because they are not subject to this complication associated with sulfur.

The weak-acid resins that contain carboxylate groups can be easily calcined in just one step in air and produce a very pure oxide product. The potential problem is that they load only at near neutrality $(\mathrm{pH}>5)$, and actinides will normally precipitate under these conditions. However, a test showed that successful loading of $\mathrm{Yb}^{3+}$ (stand-in for $\mathrm{Am}^{3+}$ and $\mathrm{Cm}^{3+}$ ) on a weak-acid resin at $\mathrm{pH}=5$ could be achieved using a acetic acid/acetate buffer. During that test, ytterbium did not precipitate in the buffer solution and remained in solution. Under these conditions, very high loading was achieved. The behavior of americium and curium is expected to be the same, but a test will be performed to validate the process.

A batch of weak-acid resin (Bio-Rex 70 50-100 mesh) in the sodium form was procured. The resin particles were sieved into four size fractions, namely, $<150 \mu \mathrm{m}, 150-212 \mu \mathrm{m}, 212-300 \mu \mathrm{m}$, and 300-330 $\mu \mathrm{m}$. Each fraction was converted to the acid form using $0.8 M \mathrm{HNO}_{3}$. The resins were then preequilibrated in an acetate buffer at $\mathrm{pH}$ 5.0. Ytterbium oxide was dissolved in nitric acid and the resulting solution buffered with acetic acid and sodium acetate to $\mathrm{pH}$ 5.0. Complexation by acetate of the $\mathrm{Yb}^{3+}$ species prevented the precipitation and allowed for the resin loading. All four size fractions were loaded with ytterbium to breakthrough, dried, and calcined. Figure 6 shows the particle size distribution as determined by sieving of the ytterbium oxide particles obtained after calcination of the resin fractions. Calcination was performed in an air atmosphere under a temperature profile that held the particles for $2 \mathrm{~h}$ at $1250^{\circ} \mathrm{C}$. The 300 - to $330-\mu \mathrm{m}$ resin fraction produced oxide particles of the desired size $(\sim 80 \mu \mathrm{m})$. The particles will be characterized (microscope imaging, porosity, and surface area) and a larger batch produced in order to prepare the surrogate rodlet. 

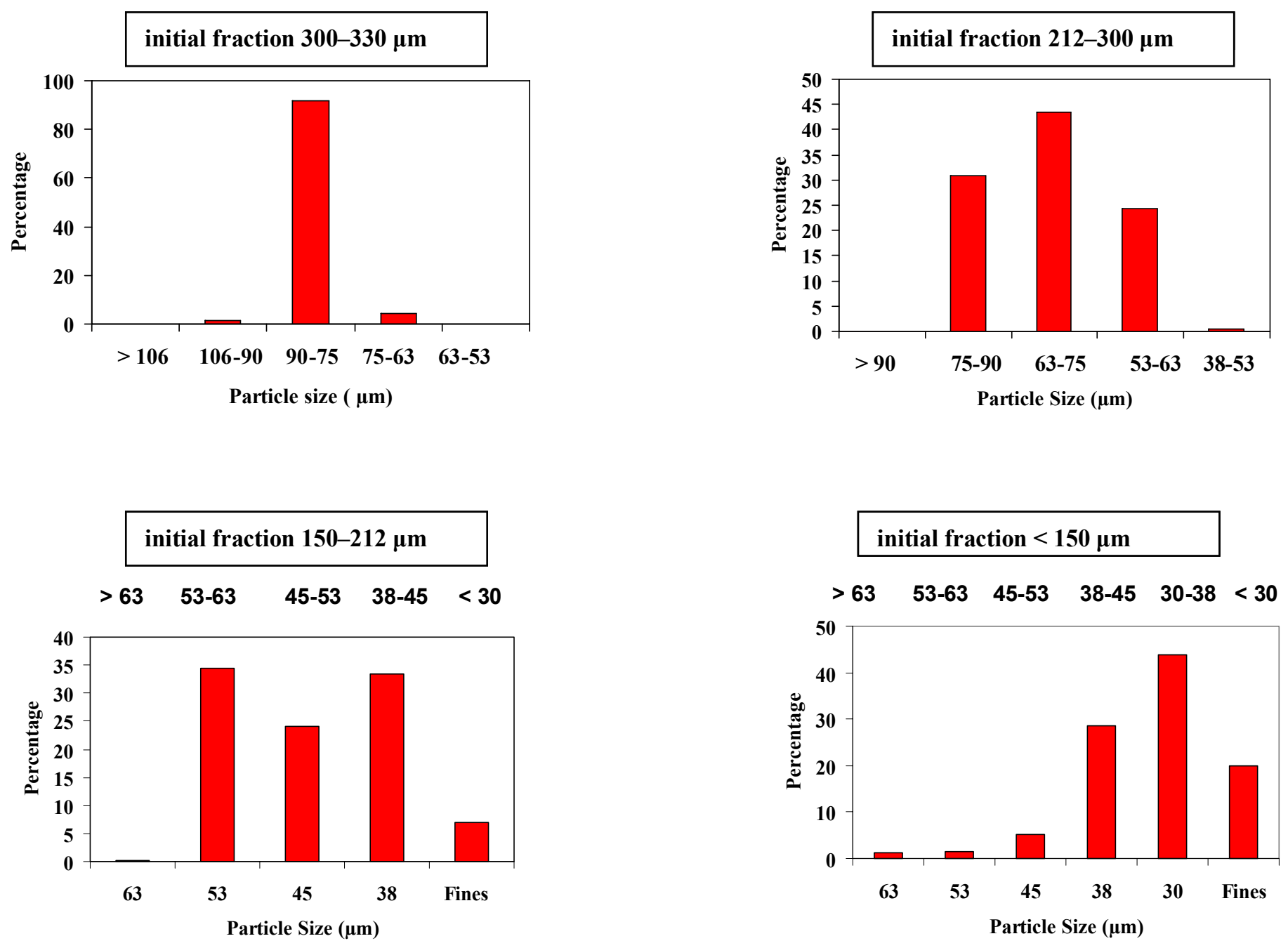

Fig. 6. Particle size distribution of the $\mathrm{Yb}_{2} \mathrm{O}_{3}$ produced by ion-exchange loading on Bio-Rex 70 resin and subsequent calcination. 


\section{PIN LOADING}

The quartz "fuel rod" and glass beads shown in Fig. 7 were used to test the equipment and to provide visual evidence of the uniformity of the rod loading. A 9-mm-ID quartz tube was loaded with two sizes of glass spheres ( 80 - and $800-\mu \mathrm{m}$ diameter) by vibratory infiltration of the smaller-size fraction. A commercial accelerometer, shown in Fig. 8, was used to provide a selectable and stable vibration motion. The volume of the tube designated for sphere-pac loading was $10 \mathrm{~cm}^{3}$. The smear density was reproducible and measured to be about $83 \%$ — close to the theoretical limit.

A special test was also done to confirm uniform loading. A rod was segmented into $2.54-\mathrm{cm}$ lengths and used to measure the uniformity of the loading. This uniformity test was conducted as follows: (a) the rod was segmented before loading, (b) the rod was reassembled as an integral tube joined by an adhesive, (c) the rod was loaded with spheres, and (d) the rod was carefully sectioned from top to bottom in such a manner as to preserve the underlying loading information. The results of this profiling method are provided in Table 4.

Table 4. Axial uniformity of sphere-pac in segmented-pin trial

\begin{tabular}{ccc}
\hline & \multicolumn{2}{c}{ Mass in segment $(\mathrm{g})$} \\
\cline { 2 - 3 } 2.54 -cm pin-segment no. & $80 \mu \mathrm{m}$ & $800 \mu \mathrm{m}$ \\
\hline 1 & 0.76 & 2.14 \\
2 & & \\
3 & 0.75 & 2.11 \\
4 & 0.73 & 2.19 \\
5 & 0.77 & 2.19 \\
\hline
\end{tabular}




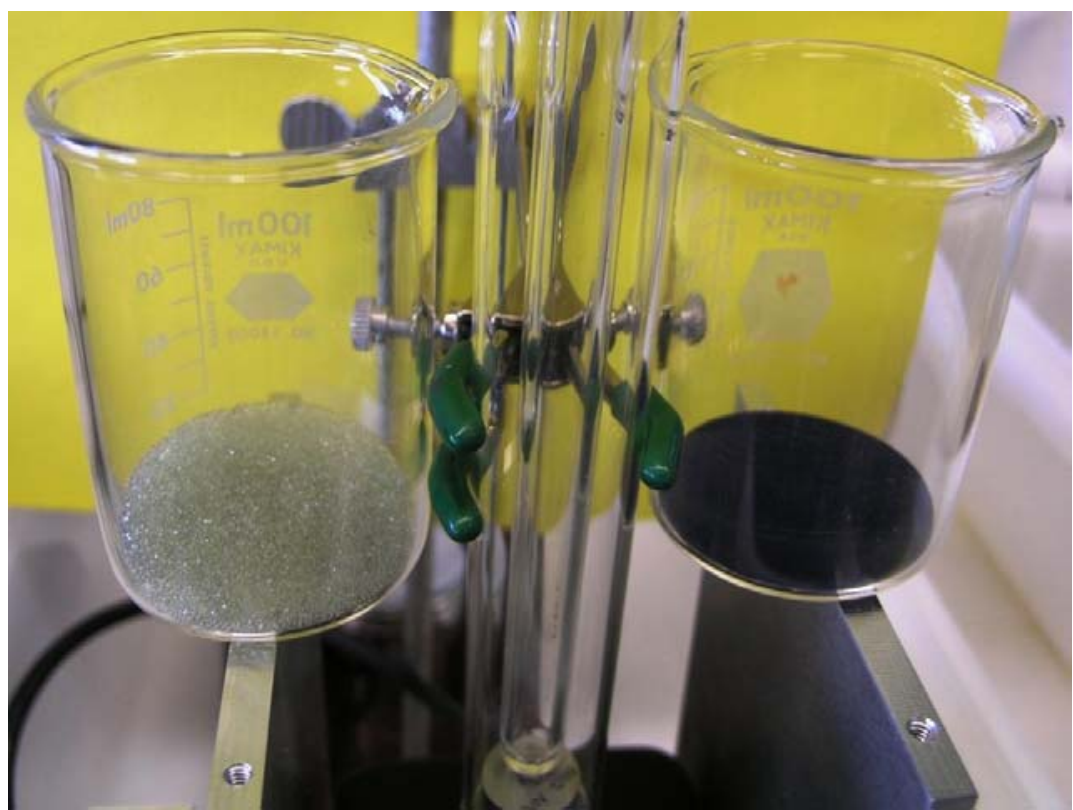

Fig. 7. Quartz "fuel rod" and glass beads used to test and optimize loading conditions.

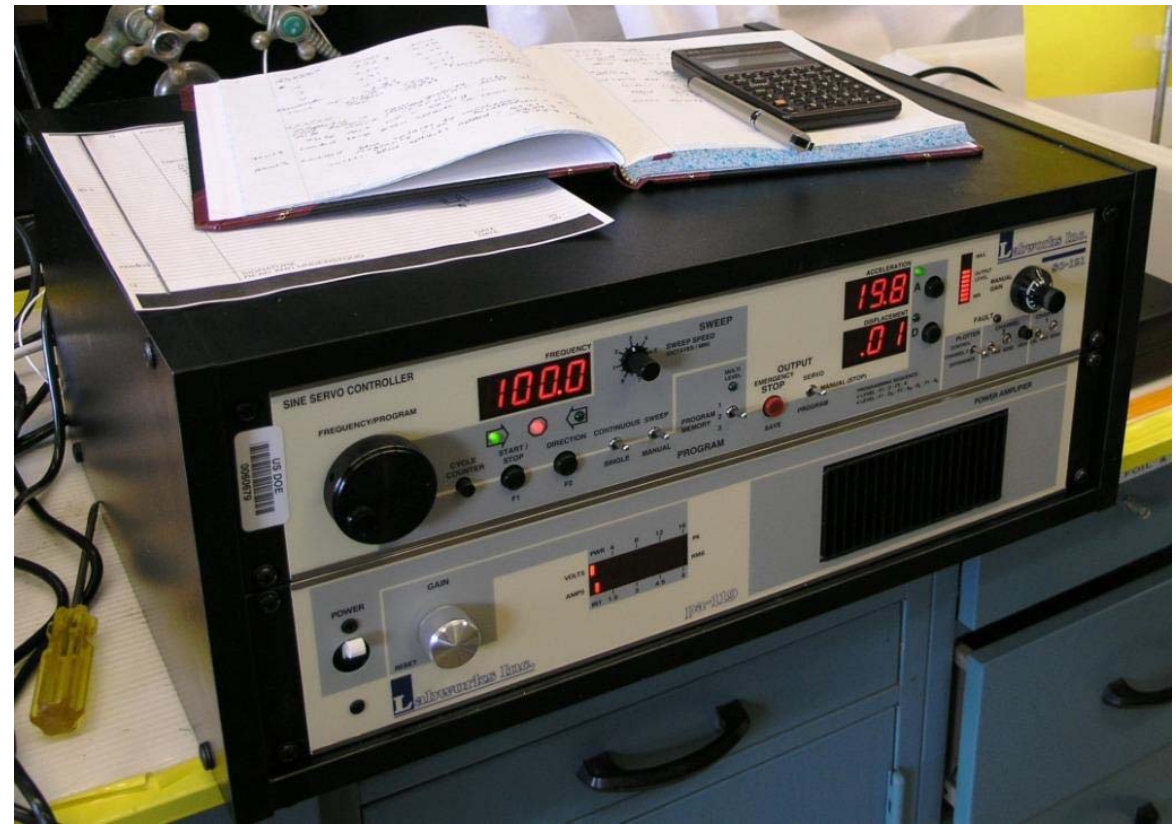

Fig. 8. Accelerometer used to impart a reproducible vibration motion to load the pin. 
The initial fuel-column loading experiments were conducted with a manual sphere-feeding system. A more automated system is needed to achieve a reproducible fuel column. An improved sphere-feeding system, shown in Fig. 9, was assembled using a low-speed variable motor, a flexible shaft, and a modified glass feeder. A follower rod, shown in Fig. 10, was fabricated that contains a mesh in the bottom. After loading the coarse fraction of spheres, this rod will be inserted into the top of the fuel pin. The fine fraction of spheres is introduced through the top of the follower rod. The rod holds the coarse fraction in

place while allowing the fine fraction to infiltrate. Additionally, the follower rod can be used as an index gage for measurement of fuel height.

Documentation of the microsphere properties (size, density, composition, impurities), fuel column properties (smear density/uniformity), and pin-loading operations will be provided as part of the fabrication documents, as described in the preceding sections. After loading, the cap will be welded into the pin, and the welded assembly will be helium leak checked. The pin will then be radiographed and inspected prior to shipment.

\section{SUMMARY}

This report provides a review of development efforts related to the fabrication of a surrogate spherepac rodlet. The surrogate sphere-pac pin will be: (a) fabricated from 316 stainless steel, (b) filled with 500- to $800-\mu \mathrm{m} \mathrm{HfO}_{2}$ spheres, (c) infiltrated with 50- to $80-\mu \mathrm{m} \mathrm{Yb}_{2} \mathrm{O}_{3}$ spheres, and (d) assembled and welded into a prototypical irradiation rodlet. The large spheres will be obtained from a commercial source, while the small spheres will be prepared at ORNL using a resin-loading/calcination process. All of the fabrication infrastructure has been established for the surrogate rodlet, and nearly all of the characterization capability exists at ORNL. A method for testing the uniformity of the fuel column with an existing X-ray instrument at ORNL will be pursued as part of the surrogate rodlet fabrication. 


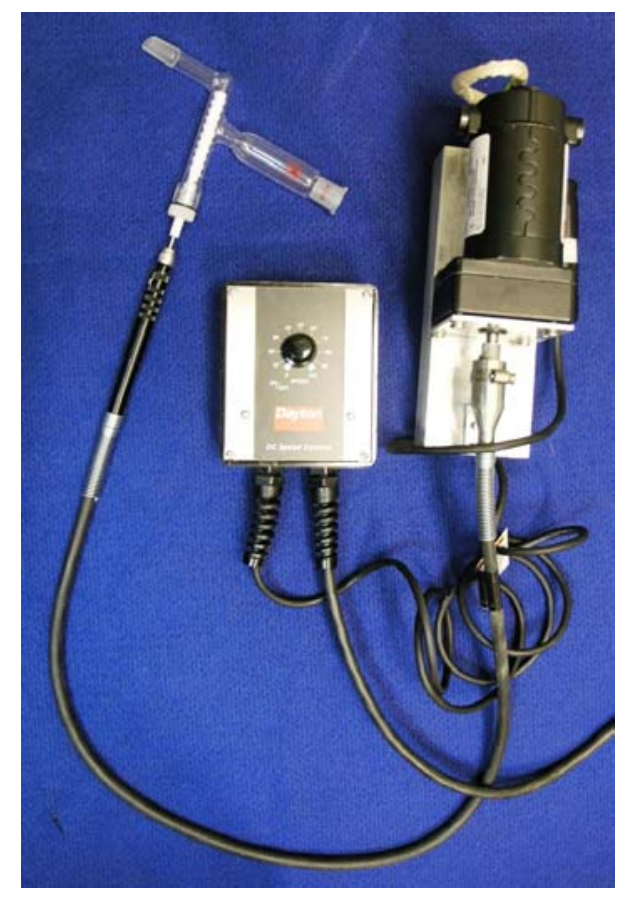

Fig. 9. Pin-loading equipment.

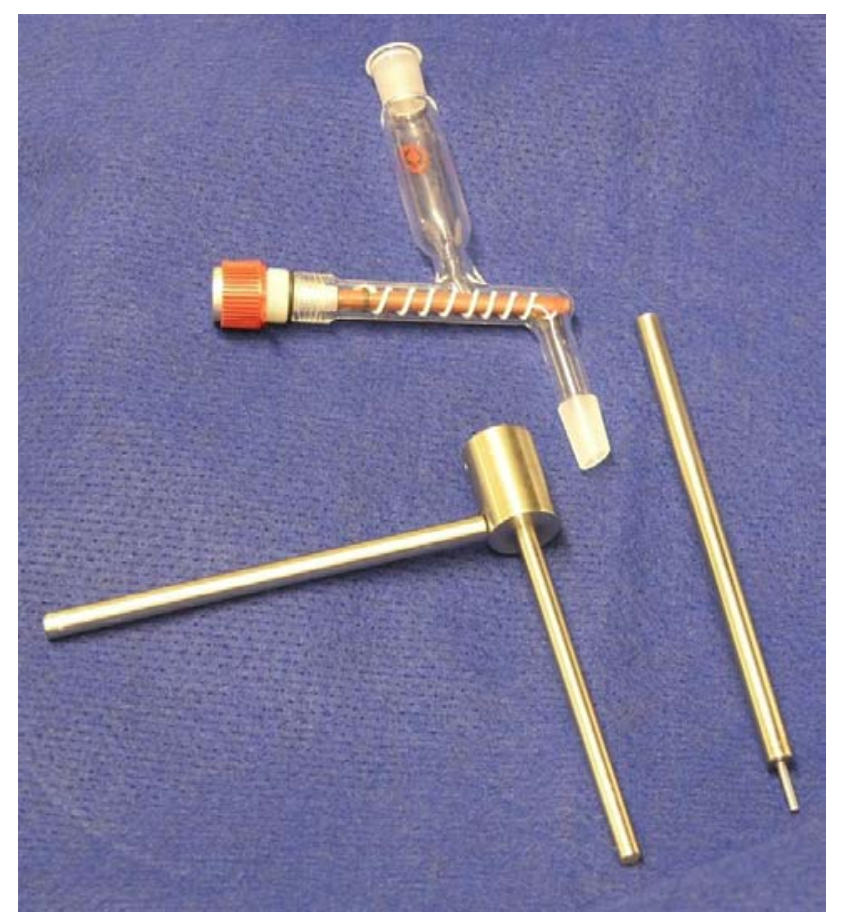

Fig. 10. Follower rod (lower left) along with fuel pin and screw feeder. 


\section{REFERENCES}

1. A. S. Icenhour and D. F. Williams, Sphere-Pac Evaluation for Transmutation, ORNL/TM-2005/41, Oak Ridge National Laboratory, Oak Ridge, Tenn., May 2005.

2. K. L. Peddicord, R. W. Stratton, and J. K. Thomas, "Analytical and Experimental Performance of Sphere-pac Nuclear Fuels,” Prog. Nucl. Energy 18(3), 265-299 (1986).

3. R. L. Beatty, R. E. Norman, K. J. Notz et al., Gel-Sphere-Pac Fuel for Thermal Reactors-Assessment of Fabrication Technology and Irradiation Performance, ORNL-5469, Oak Ridge National Laboratory, Oak Ridge, Tenn., November 1979.

4. W. J. Lackey, J. E. Selle et al., Assessment of Gel-Sphere-Pac Fuel for Fast Breeder Reactors, ORNL5468, Oak Ridge National Laboratory, Oak Ridge, Tenn., October 1978.

5. A. L. Lotts et al., Fast Breeder Reactor Oxide Fuels Development_Final Report, ORNL-4901, Oak Ridge National Laboratory, Oak Ridge, Tenn., November 1973.

6. A. E. R. Westman and H. R. Hugill, "The Packing of Particles," J. Am. Ceram. Soc. 13, 767-779 (1930).

7. R. K. McGeary, "Mechanical Packing of Spherical Particles," J. Am. Ceram. Soc. 44(10), 513-522 (1961).

8. M. A. Pouchon et al., "Fabrication and Characterization of MOX Microspheres for the FUJI Project," p. 653 in Proceedings of Global 2003, American Nuclear Society, New Orleans, LA, November 16-20, 2003, American Nuclear Society, La Grange Park, Ill., 2003.

9. C. Hellwig et al., "Sphere-pac Filling for Irradiation Tests of the FUJI Project," pp. 1348-1353 in Proceedings of Global 2003, American Nuclear Society, New Orleans, LA, November 16-20, 2003, American Nuclear Society, La Grange Park, Ill., 2003.

10. Y. Shigetome et al., "Vipac Fuel Fabrication for Irradiation Tests of the FUJI Project," pp. 13421347 in Proceedings of Global 2003, American Nuclear Society, New Orleans, LA, November 16-20, 2003, American Nuclear Society, La Grange Park, Ill., 2003.

11. A. A. Maershin et al., "Development and Testing of Fuel Elements with Vibrationally Compacted Oxide Fuel for Fast Reactors," At. Energy 91(5), 923-930 (2001).

12. A. F. Gratchyov et al., "Results of In-Pile Tests and PIE of the BN-600 FAs Containing Weapon Grade Plutonium," p. 1341 in Proceedings of Global 2003, American Nuclear Society, New Orleans, LA, November 16-20, 2003, American Nuclear Society, La Grange Park, Ill., 2003.

13. A. Puill, J. Bergeron, M. Rohart et al., "Progress in the Studies of the Advanced Plutonium Fuel Assembly," Prog. Nucl. Energy 38 (3-4), 403-406 (2001).

14. J. Brochard, S. Bourreau, N. Hourdequin et al., "Specific fuel rod thermomechanical studies for the Advanced Plutonium fuel Assembly concept," Prog. in Nuc. Energy 38 (3-4), 399-402 (2001). 
15. J. L. Collins, R. D. Hunt, G. D. Del Cul, and D. F. Williams, Production of Depleted $\mathrm{UO}_{2}$ Kernels for the Advanced Gas-Cooled Reactor Program for Use in TRISO Coating Development, ORNL/TM2004/123, Oak Ridge National Laboratory, Oak Ridge, Tenn., November 2004.

16. F. R. Chattin, D. E. Benker, M. H. Lloyd, P. B. Orr, R. G. Ross, and J. T. Wiggens, "Preparation of Curium-Americium Oxide Microspheres by Resin-Bead Loading," pp. 173-185 in Transplutonium Elements-Production and Recovery, ACS Symposium Series 161, ed. J. D. Navratil and W. Schulz, American Chemical Society, Washington, D.C., 1981.

17. D. R. Johnson, W. J. Lackey, and J. D. Sease, "The Effects of Processing Variables on HTGR Fuel Kernels Fabricated from Uranium-Loaded Cation-Exchange Resin," Am. Ceram. Soc. Bull. 56(6), 567571 (1977).

18. K. J. Notz, P. A. Haas, and J. H. Shaffer, "The Preparation of HTGR Fissile Fuel Kernels by Uranium-Loading of Ion Exchange Resins," Radiochim. Acta 25, 153-160 (1978).

19. B. E. Foster and S. D. Snyder, "Evaluation of Variables in the Measurement of Fuel Concentration Variations in Fuel Rods," Materials Evaluation, 27-32 (February 1968).

20. M. A. Pouchin, M. Nakamura, Ch. Hellwig, F. Ingold, and C. Degueldre, "Cermet sphere-pac concept for inert matrix fuel," J. Nucl. Mater. 319, 37-43 (2003). 
ORNL/TM-2005/108

\section{INTERNAL DISTRIBUTION}

$\begin{aligned} \text { 1. } & \text { C. W. Alexander } \\ 2 . & \text { E. D. Collins } \\ 3-7 . & \text { G. D. Del Cul } \\ 8 . & \text { M. Du } \\ 9-11 . & \text { L. K. Felker } \\ 12 . & \text { D. J. Hill } \\ 13-15 . & \text { A. S. Icenhour } \\ 16 . & \text { D. T. Ingersoll }\end{aligned}$

$\begin{aligned} 17 . & \text { B. E. Lewis } \\ 18-20 . & \text { C. H. Mattus } \\ 21 . & \text { J. E. Rushton } \\ 22 . & \text { B. B. Spencer } \\ 23 . & \text { R. M. Wham } \\ 24-26 . & \text { D. F. Williams } \\ 27 . & \text { NSTD DMC } \\ 28 . & \text { ORNL OTIC-RC, OSTI, CRL }\end{aligned}$

EXTERNAL DISTRIBUTION

29. F. J. Goldner, Office of Advanced Nuclear Research, U.S. Department of Energy, NE-20, Germantown Building, 1000 Independence Avenue, S.W., Washington, DC 20585-1290.

30. J. E. Kelly, Sandia National Laboratory, P.O Box 5800, Albuquerque, NM 87185-0771.

31. S. R. Martin, Oak Ridge National Laboratory, P.O. Box 2008, Oak Ridge, TN 37831-6269

32. K. Pasamehmetoglu, Idaho National Laboratory, P.O. Box 2528, Idaho Falls, ID 83404-2528.

33. C. D. Savage, Office of Advanced Nuclear Research, U.S. Department of Energy, NE-20, Germantown Building, 1000 Independence Avenue, S.W., Washington, DC 20585-1290. 